\title{
Evaluating the Suitability of Qualitative Methods in Wakaf-Zakat Housing Provision Research
}

\author{
Azila Ahmad Sarkawi, Jamilah Othman
}

\begin{abstract}
Research on wakaf-zakat housing provision is a cross-disciplinary. It involves an area of study under religion and the built environment by wakaf-zakat and housing, respectively. , A combination of these two areas of study, requires a well-defined research methodology that the paper evaluates the suitability of qualitative methods to achieve the stipulated research objectives. Consequently, attainment of each research objective through specified methods is explained either by way of interview, case-study, observation and focus-group-discussion. Insequent, after an extensive literature review was conducted, the instrument for data collection was instituted. It was piloted through a focus-group-discussion (FGD), and the amendments to the instrument was made accordingly. Then, the data collection was done through case-studies and observations of wakaf-zakat housing projects as well as interviews. Experts in religious studies and the built environment were selected for the above FGD and interviews. The data collected was critically analysed by way of content analysis. The outcome of the analysis was presented to the experts again for validation. For FGD and interviews, the purposive sampling with a high degree of respondent selection criteria is adopted. Overall, the study found that those qualitative methods are suitable to achieve the stipulated objectives for wakaf-zakat housing provision research
\end{abstract}

Index Terms: Wakaf; Zakat; Research; Qualitative Methods.

\section{INTRODUCTION}

Research is one way of knowledge acquiring process. It is governed by the consented methodology to ensure its reliability and validity of results or knowledge acquired. Furthermore, the term 'research' suggests that it is looking for something already in existence, i.e. available information that the researchers search for and put it into the intended context of knowledge. Research is highly demanded both in Islam 1 and the secular world. About degree of evidence, methodological thoroughness is determined by the scope to which the study follows to the principles such as methodological validity, appropriateness and transparency, Sound data collection and Triangulation concentrating on the mixed method (www.Enterprise-Development.org).:

With regard to wakaf-zakat housing provision research, matters related to Islamic rulings are inevitable. The research

Revised Manuscript Received on September 22, 2019.

Azila Ahmad Sarkawi, International Islamic University Malaysia, azila@iium.edu.my

Jamilah Othman, International Islamic University Malaysia piece of news, inquire first into its truth, lest you should wrong others unwittingly and repent of what you have done".
${ }^{1} \mathrm{Al}$-Qur'an, al-Hujurat:06; “O believers! If a wicked person brings you a

is a cross-disciplinary in nature, thus requires a well-defined methodology between Islamic legal theory (Usul al-fiqh) and conventional research methods. In so doing, the study discusses the conventional methodology of research conduct and the performance of ijtihad in Islamic studies as well as their respective research methods. The discussion revolves around the integration of Islamic principles wakaf and zakat in the conventional way of housing provision. At the onset, the study aims to determine the suitability of conventional qualitative methods in research involving Islamic matters without compromising its religious requirements.

\section{WAKAF-ZAKAT HOUSING PROVISION RESEARCH}

Housing is one of the categories for the development of wakaf land other than religion, education, health, agriculture, business and services and infrastructure and facilities. Whereby, housing-related assistances also appear as one of the schemes under the zakat disbursement ranging from building a house on asnaf's owned or permitted land, deposit for low-cost housing, deposit for rental, monthly house rental, repair etc. Thus, the research is looking into the shariah permissibility of combining these two Islamic socio-economic resources towards providing housing to the needy and snaf (zakat recipient).

A review on the Wakaf Development Transformation Master Plan Study (Yayasan Waqaf Malaysia, 2016) suggests that wakaf authority involves in providing housing to the nation. The development of wakaf land in Malaysia gained momentum with the formation of Jabatan Wakaf, Haji and Zakat (JAWHAR) in 2004 under the Prime Minister's Department. In the Ninth Malaysian Plan (2006-2010), several projects on wakaf land were planned, and some financial budget was allocated to JAWHAR for that purpose. Indeed, Muzakarah Jawatankuasa Fatwa Majlis Kebangsaan for Islamic affairs, which was seized in April 2007 has granted the auction of lease to parts that were built on wakaf land including housing. These scenarios led to the establishment of Yayasan Wakaf Malaysia (here and after that referred to as YWM) in 2008 with the aim, amongst others, to accelerate the development of wakaf land in Malaysia.

The drive towards developing wakaf land in particular for housing is in line with the National Housing Policy (2011) that demands the collaboration between JAWHAR, State Islamic Religious Council 
(SIRC) and Local Authority. The strategies in housing the nation have been a continuing effort translated into the 5-Year Malaysia Strategy. The Eleventh Malaysia Plan (2016-2020) has spelt out in its Strategy Paper 6 the utilization of potential wakaf and baitulmal land for the purpose of reasonable housing. In National Physical Plan 3, the provision of affordable housing on wakaf land has also been mentioned under its Thrust 3, i.e. development of the inclusive and liveable community.

The administration of wakaf in Malaysia is under the purview of the State Islamic Administration Enactment, as shown in Table 1. There are specific sections on wakaf in the respective Enactments (specified in the brackets) added with specific wakaf Enactment for five States.

Table 1: States' governing wakaf management

\begin{tabular}{|c|c|c|}
\hline NO & STATES & STATES' ENACTMENTS \\
\hline 1 & $\begin{array}{l}\text { Penang } \\
\text { (ss.89-95) }\end{array}$ & $\begin{array}{l}\text { Administration of the Religion of Islam } \\
\text { (State of Penang) Enactment } 2004\end{array}$ \\
\hline 2 & \begin{tabular}{|l|l}
$\begin{array}{l}\text { Perlis } \\
\text { (ss.89-95) }\end{array}$ \\
\end{tabular} & $\begin{array}{l}\text { Administration of the Religion of Islam } \\
\text { Enactment } 2006\end{array}$ \\
\hline 3 & $\begin{array}{l}\begin{array}{l}\text { Kedah } \\
(\mathrm{ss} .51-58)\end{array} \\
\end{array}$ & $\begin{array}{l}\text { Administration of Islamic Law (Kedah } \\
\text { Darul Aman) Enactment } 2008\end{array}$ \\
\hline 4 & $\begin{array}{l}\text { Perak } \\
\text { (ss.78-84) }\end{array}$ & $\begin{array}{l}\text { Administration of the Religion of Islam } \\
\text { (Perak) Enactment } 2004 \\
\text { Wakaf Enactment (Perak) } 2015 \\
\end{array}$ \\
\hline 5 & $\begin{array}{l}\text { Selangor } \\
\text { (ss.89-95) }\end{array}$ & $\begin{array}{l}\text { Administration of the Religion of Islam } \\
\text { (State of Selangor) Enactment } \\
\text { 2003-Perintah Penubuhan Perbadanan } \\
\text { Wakaf Selangor 2011 } \\
\text { Wakaf (State of Selangor) Enactment } \\
\mathbf{2 0 1 5}\end{array}$ \\
\hline 6 & $\begin{array}{l}\text { Federal } \\
\text { Territories } \\
\text { (ss.61-68) } \\
\end{array}$ & $\begin{array}{l}\text { Administration of Islamic Law (Federal } \\
\text { Territories) Act } 1993\end{array}$ \\
\hline 7 & $\begin{array}{l}\text { Melaka } \\
\text { (ss.77-83) }\end{array}$ & $\begin{array}{l}\text {-Administration of the Religion of Islam } \\
\text { (State of Malacca) Enactment } 2002 \\
\text {-Melaka Wakaf Enactment } 2005\end{array}$ \\
\hline 8 & $\begin{array}{l}\text { Negeri } \\
\text { Sembilan } \\
\text { (ss.89-95) }\end{array}$ & $\begin{array}{l}\text {-Administration of the Religion of Islam } \\
\text { (Negeri Sembilan) Enactment } 2003 \\
\text {-Negeri Sembilan Wakaf Enactment } \\
\mathbf{2 0 0 5}\end{array}$ \\
\hline 9 & $\begin{array}{l}\text { Johor } \\
\text { (ss.89-95) }\end{array}$ & $\begin{array}{l}\text {-Administration of the Religion of Islam } \\
\text { (State of Johor) Enactment } 2003 \\
\text {-Johor Wakaf Rules } \mathbf{1 9 8 3} \\
\end{array}$ \\
\hline 10 & $\begin{array}{l}\text { Pahang } \\
\text { (ss.70-78) }\end{array}$ & $\begin{array}{l}\text {-Administration of Islamic Law } \\
\text { Enactment } 1991\end{array}$ \\
\hline 11 & $\begin{array}{l}\text { Terengganu } \\
(\mathrm{ss} .63-69)\end{array}$ & $\begin{array}{l}\text {-Administration of Islamic Religious } \\
\text { Affairs (Terengganu) Enactment } 1422 \mathrm{H} \\
\text {-Terengganu Wakaf Enactment } 2015\end{array}$ \\
\hline 12 & $\begin{array}{l}\begin{array}{l}\text { Kelantan } \\
\text { (ss.61-66) }\end{array} \\
\end{array}$ & $\begin{array}{l}\text {-Council of the Religion of Islam \& } \\
\text { Malay Custom Kelantan Enactment } 1994\end{array}$ \\
\hline 13 & \begin{tabular}{|l} 
Sabah \\
(ss.51-57)
\end{tabular} & $\begin{array}{l}\text {-Majlis Ugama Islam Negeri Sabah } \\
\text { Enactment } 2004\end{array}$ \\
\hline 14 & $\begin{array}{l}\text { Sarawak } \\
\mathrm{s} .43,51-54)\end{array}$ & $\begin{array}{l}\text {-Majlis Islam Sarawak Ordinance } 2001 \\
\text { (Chap. 41) }\end{array}$ \\
\hline
\end{tabular}

Source: Adapted from Sharifah Zubaidah \& Nor Asiah, 2017, pg.92-94.

Likewise, wakaf, zakat provisions are included in the Enactment of Islamic affairs administration of each state in Malaysia. The provisions are supported by subsidiary laws

and rules for implementation. The state of Selangor, for instance, it has Administration of the Religion of Islam Enactment 2003 (here and after that denoted as ARIE 2003) for which zakat is mentioned in Sections 86 to 88. On top of that, it has Zakat and Fitrah Regulations 2012. Talking about the distribution of zakat fund, reference to the Fatwa Committee for any amendments or changes made to the current practice, in this case, using zakat fund for mass housing development is required by the Regulations. This legislation framework of zakat administration is quite similar to other states in Malaysia. Table 2 summaries the structure of zakat administration in Malaysia.

Table 2: Zakat administration in Malaysia

\begin{tabular}{|l|l|}
\hline Structure & States \\
\hline $\begin{array}{l}\text { Zakat administration solely by SIRC } \\
\text { for both collection and distribution }\end{array}$ & $\begin{array}{l}\text { Johore, Perak, Perlis, } \\
\text { Kelantan, Terengganu }\end{array}$ \\
\hline $\begin{array}{l}\text { Dwi-system zakat administration, } \\
\text { i.e. collection by a subsidiary, } \\
\text { distribution by SIRC }\end{array}$ & $\begin{array}{l}\text { Federal Territories, } \\
\text { Negeri Sembilan, } \\
\text { Melaka, Pahang }\end{array}$ \\
\hline $\begin{array}{l}\text { Privatization of both collection and } \\
\text { distribution of zakat on behalf of } \\
\text { SIRC }\end{array}$ & $\begin{array}{l}\text { Selangor, Pulau } \\
\text { Pinang, Sabah, } \\
\text { Sarawak }\end{array}$ \\
\hline $\begin{array}{l}\text { Separated from SIRC but it is under } \\
\text { the Sultan of the state }\end{array}$ & Kedah \\
\hline
\end{tabular}

Source: Adapted from Eza Ellany et al., 2014

Both areas of wakaf and zakat require fatwa for their execution. In this respect, Section 47 of ARIE 2003 states that fatwa could be sought by any individual $\mathrm{m}$ from Mufti, or by the direction of His Royal Highness, the Sultan or the Fatwa Committee formulate fatwa on some disturbed or controversial question of or linking to Hukum Syarak on its initiative. About the power of the Fatwa Committee to prepare a fatwa according to the procedure. Upon receiving a request for a fatwa, the Mufti can lead to research or study as oriented by him and a working document to be arranged. The request will undergo a process of discussion amongst the Fatwa Committee's members specified in Section 46 of the Enactment. The prepared fatwa shall be submitted to the SIRC for deliberation and recommendation be made to the Sultan for his approval. The assented fatwa shall be informed to the State Government to be printed in the official Gazette. Once it is published, a fatwa becomes obligatory on every Muslim in the State and recognized by all courts in the State Similarly to wakaf, a fatwa is sought for, as stated in Section 40 of its Waqaf Enactment 2015:

"Where there is any question on Hukum Syarak in connection with the pillars of wakaf or matter incidental to it which needs to be determined, the Corporation shall refer to the Fatwa Committee as to the question."

Looking at the current scenario of wakaf and zakat administration in Malaysia where charge to the Fatwa Committee is compulsory by the law, the wakaf-zakat housing provision research needs to adopt and adapt the current practice with regards to their shariah matters. Interview and focus-group-discussion are among the conventional qualitative methods suitable to attain the following research's objectives: 
1. to identify key indicators in the provision of wakaf-zakat housing

2. to determine the shariah legitimacy based on (1) in the provision of wakaf-zakat housing

3. to develop an appropriate benchmark for assessing the shariah legitimacy in the provision of wakaf-zakat

4. to validate the benchmark established in (3) above.

\section{QUALITATIVE VS. QUANTITATIVE APPROACH FOR WAKAF-ZAKAT HOUSING RESEARCH}

Conventionally, the study is a logical and methodical search for novel and valuable information on a specific topic aiming at obtaining reliable knowledge. The 'truth' was not used in the description of the study as its achievement is regarded as beyond human mental capability. Key components of research are the systematic and orderly following a series of steps and the purpose to produce new reliable knowledge. This is a general basis of research that applies to all disciplines. Its characteristics could be described as (i) objective, (ii) precise, (iii) verifiable, (iv) parsimonious, (v) empirical, (vi) logical, and (vii) probabilistic.

Briefly, the research is started with a problem. Following, goals and objectives are arranged to handle the problem. The next, the research design is formulated to attain the objectives, followed by results are produced by conducting the research. Finally, explanation and investigation of outcomes being made. In between, population and sampling, instrumentation, data collection are the crucial activities.

In conventional practice, qualitative and quantitative approaches are common divisions of research that carry their specific modes and conducts. Selecting these two research approaches depends upon the researchers' (i) Research Questions, (ii) Research Goals, (iii) Researcher Beliefs and Values, (iv) Researcher Skills,' (v) Time and Funds. Figure 1 indicates the variations across the research concept.

\begin{tabular}{|c|c|c|}
\hline \multicolumn{2}{|l|}{ Qualitative methods and data } & Quantitative methods and data \\
\hline Rich & Information & Narrow \\
\hline Subjective & Interpretation & Objective \\
\hline Realistic, naturalistic & Setting & Artificial \\
\hline Loosely or non-structured & Design & Highly structured \\
\hline High & Realism & Low \\
\hline Low & Reliability & High \\
\hline High & Reflexivity & Low/non-existent \\
\hline
\end{tabular}

Fig. 1: Variations across research concept

Source: Coolican, 2004, pg.48.

Based on the objectives stipulated for wakaf-zakat housing provision research, incumbent upon seven aspects of the variations across research concept for qualitative and quantitative research shown in Figure 1, it can be said that the research inclines towards the qualitative approach. Table 3 helps to confirm this view looking from the pros and cons of qualitative and quantitative research approach respectively:
Table 3: pros and cons of qualitative and quantitative research

\begin{tabular}{|ll}
\hline \multicolumn{1}{|c}{ Quantitative } & \multicolumn{1}{c}{ Qualitative } \\
\hline - Relatively easy to administer, & - Captures more depth and provide insights as to \\
the 'why"' and "how'
\end{tabular}

Source: Mohammad Muaz Jalil,

www.Enterprise-Development.org.

Another way of categorising research is whether it is deductive or inductive. Deductive research is theory-testing, which is often linked to datasets, surveys or quantitative analysis. Inductive research is theory-generating and is often linked to qualitative analysis. The research could also be classified as empirical or theoretical. An empirical study could involve close analysis of statistics or some form of quantitative research. However, a theoretical study brings its challenges to compare theories in terms of their applicability. In a statistical package, it determines the analysis tools that to be used about the research objectives as shown in the following Table 4:

Table 4: Research objectives and its analysis tools in a statistical package.

\begin{tabular}{|c|c|c|}
\hline \begin{tabular}{|l} 
Describing \\
Phenomenon \\
\end{tabular} & $\begin{array}{l}\text { Comparison } \\
\text { between Groups }\end{array}$ & $\begin{array}{l}\text { Relationship } \\
\text { between Variable }\end{array}$ \\
\hline 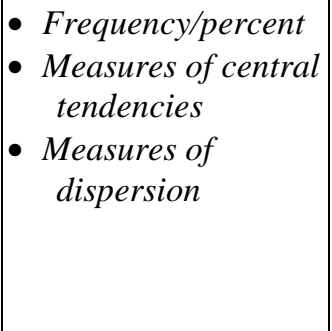 & $\begin{array}{l}\text { - T-Test } \\
\text { - ANOVA } \\
\text { - Mann-Whitney } \\
\text { - Kruskal Wallis }\end{array}$ & \begin{tabular}{|c} 
- Chi-square \\
- Spearman \\
rank \\
correlation \\
- Pearson PM \\
correlation \\
- Regression \\
analysis
\end{tabular} \\
\hline
\end{tabular}

Source: Bahaman, 2015.

Delving into the objectives of wakaf-zakat housing provision research and the explanation of a qualitative and quantitative approach of study, it is apparent that the research is qualitative from the conventional research practice.

\section{A. IJTIHAD AND USUL AL-FIQH}

Likewise, research in the quest of knowledge is a collective obligation (fard kifayah) in Islam to the extent Allah SWT indirectly distinguishes people with knowledge from people without knowledge ${ }^{2}$, while knowledge-seeking is an individual obligation (fard 'ain) $)^{3}$. Indeed, Islam laid down Al-Qur' an and Al-Sunnah as leading sources of knowledge. Meaning to say knowledge acquisition must be based on these two sources in which they were called revealed knowledge. Another category of knowledge in Islam has acquired knowledge through which human mental capability is harnessed. The process of acquiring human knowledge from its principal sources is called Ijtihad (human interpretation). There is no dispute in terms of the former

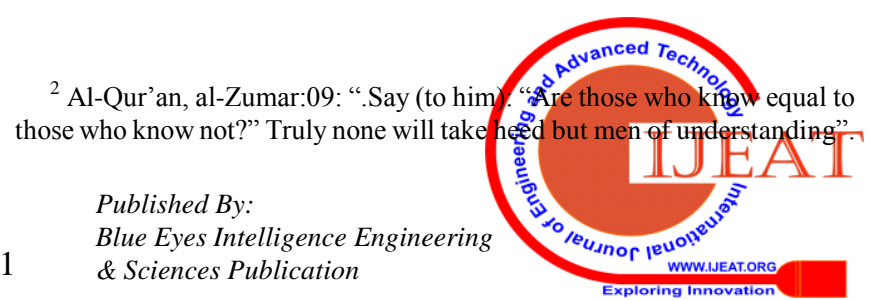


category of knowledge. However, the latter is a alarming it includes human reasoning. In this regard, Islam puts clear demarcation between researchable and non-researchable items of its principal sources, which the former is a subject matter of ijtihad. In doing so, ijtihad is delineated by specific methodology similarly to ensure its legitimacy. This specified methodology is called Usul al-figh. Though the founding Muslim jurists did not make a clear division between qualitative and quantitative research, the available published materials suggest that contemporary qualitative research is conceptually inter-related with the Islamic jurisprudence (Usul Al-Fiqh) governing the process of ijtihad.

Ijtihad is defined as "the total expenditure of efforts made by a jurist to infer, with a degree of probability, the rules of shari'ah from their detailed evidence in the sources" (quoted in Kamali,1991:367). By its technical meaning, ijtihad excludes the taking out a decision from a clear writing. It also eliminates the finding of a hukm by requesting a scholar or by referring the related literature deprived of of individual's belief and conclusion, but at least it relates to something. As a knowledge source in Islam, the thorough evidences found in the Qur'an and the Sunnah are distributed into the following four categories:

$i$. Evidence that is conclusive both regarding legitimacy and meaning,

ii. Evidence that is reliable but hypothetical in meaning,

iii. Evidence that is uncertain, but certain in meaning,

$i v$. Evidence which is hypothetical regarding legitimacy and meaning.

Ijtihad does not put on to the first of the previous types (Kamali, 1991, pg. 368).

Usul al-fiqh is the basis of Islamic law through which the rule of fiqh is realized from the sources. In other words, al-Qur'an and al-Sunnah are the bases from which fighs are deduced through the methodology of usul al-fiqh. The latter is very much concern with the methods of reasoning such as ijma', qiyas, istislah, istihsan, istishab, 'urf and sadd zara' $i$, while the former is knowledge of practical revealed rulings.

Table 5: Brief description of the various methods of reasoning

\begin{tabular}{|c|l|l|}
\hline NO & \multicolumn{1}{|c|}{ METHODS } & \multicolumn{1}{c|}{ BRIEF DESCRIPTIONS } \\
\hline $\mathbf{1}$ & $\begin{array}{l}\text { Ijma' (juristic } \\
\text { consensus) }\end{array}$ & $\begin{array}{l}\text { unanimous agreement of the } \\
\text { mujtahidun. }\end{array}$ \\
\hline $\mathbf{2}$ & $\begin{array}{l}\text { Qiyas } \text { (analogical } \\
\text { deduction) }\end{array}$ & $\begin{array}{l}\text { extension of a shari'ah for a new } \\
\text { case }\end{array}$ \\
\hline $\mathbf{3}$ & $\begin{array}{l}\text { Istislah } \\
\text { (considerations of } \\
\text { public interest) }\end{array}$ & $\begin{array}{l}\text { Unrestricted public interest in the } \\
\text { sense of its not having been } \\
\text { regulated by the Law giver insofar } \\
\text { as no textual authority can be } \\
\text { found on its validity or otherwise. }\end{array}$ \\
\hline $\mathbf{4}$ & $\begin{array}{l}\text { Istihsan (juristic } \\
\text { preference) }\end{array}$ & $\begin{array}{l}\text { Personal opinion exercising of the } \\
\text { current law. }\end{array}$ \\
\hline $\mathbf{5}$ & Istishab & -rational proof \\
\hline $\mathbf{6}$ & 'Urf (custom) & -recurring practices. \\
\hline $\mathbf{7}$ & Sadd al-dhara'i $i$ & -blocking the means to an expected \\
\hline
\end{tabular}

${ }^{3}$ Sahih Muslim, Book xx;xxxx: "Prophet Muhammad (saws) said: "Seeking Knowledge is obligatory upon every Muslim." (Related by Ibn 'Adiyy, Al-Bayhaqi \& Al-Tabarani). the literal meaning of ijtihad that is self-exertion of learning

\begin{tabular}{|l|l|l|}
\hline $\begin{array}{l}\text { (blocking the } \\
\text { means) }\end{array}$ & $\begin{array}{l}\text { end which is likely to materialise if } \\
\text { the means towards it is not } \\
\text { obstructed-must necessarily be } \\
\text { understood to imply blocking the } \\
\text { means to evil, not to something } \\
\text { good. }\end{array}$ \\
\hline
\end{tabular}

Source: Kamali, 1991.

The various methods of reasoning are all appearances of ijtihad, albeit with dissimilarities that are largely procedural in character. The study of Usul Al-Fiqh is planned to form a support to the accurate understanding of the sources and the comprehensive behavior of ijtihad. The Figure 4 shows the the outcome of the eight objectives of research aforesaid mentioned through ijtihad.
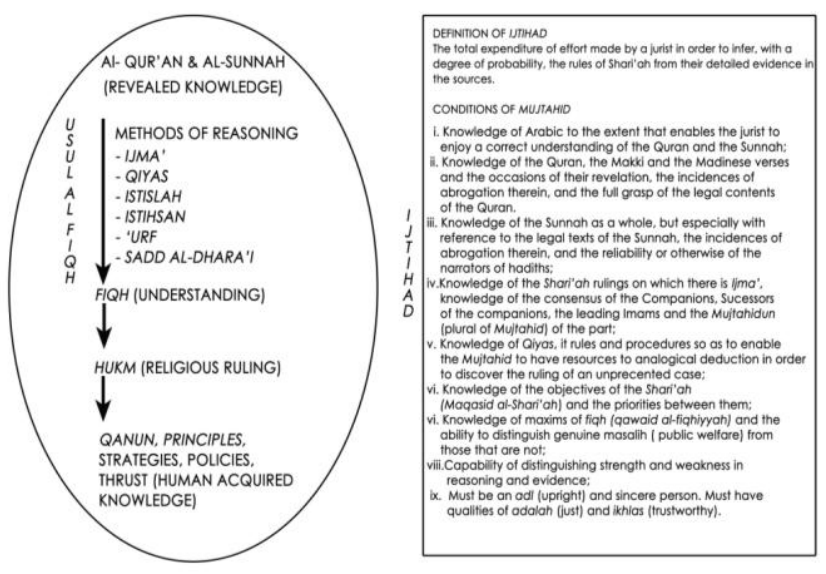

Fig. 4: Knowledge through ijtihad

Based on the Qur'an and the Sunnah, ijtihad provides understanding at a number of stages, Fiqh advances into hukm and finally into qanun. "Fiqh is an understanding, comprehension and gaining knowledge of the religion in general or knowledge of practical revealed rulings extracted from detailed evidence" (Auda, 2008, pg. 56). Deprived of additional understanding or procedure of ijtihad, fiqh remains as a general understanding; so, the next step is to distil it into hukm, i.e. religious rulings that constitute the following:

(i) Fard or wajib

(ii) Sunnah

(iii) Mubah (permissible, indifferent);

(iv) Makruh (abominable, undesirable);

(v) Haram (prohibited, unlawful).

In the opinion of present lawmaking, the hukm must go through certain lawful modifications to become a law of one state; else, it cannot be imposed because of the lack of its legal status. However Muslims are faithfully bound at the hukm level, not essentially till the qanun level (Azila, 2009).

In summary, IN Islam, al-Qur'an and Al-Sunnah are the knowledge sources and ijtihad pays considerable attention to them. $U$ It is evident that sciences of the Qur'an and sciences of the Hadith are part of the discussion under a study of usul al-fiqh, together with their rules of interpretation. Usul al-fiqh exemplifies the learning of the sources of Islamic law and methodology for its development. It offers standards for the correct evaluation and understanding of almost any 
branch of Islamic learning. This body of knowledge gives credentials to Islamic jurisprudence to the extent that Islamic jurisprudence exhibits greater stability and continuity of values, thought and institutions when compared to western jurisprudence.

Up to this point, ijtihad and Usul al-fiqh are intertwined likewise, conventional research practice and its methodology. The process of ijtihad discloses the use of reason in knowledge building. Thus, 'Abdul Hamid (1994,p.11) asserted that "there is no problem in saying that revelation and reason are the sources of knowledge in Islam, but the problem lies in defining and giving a concrete shape to the relationship between the two[...]revelation cannot function in the absence of a rational mind, and the rational mind is not worthy of recognition or respect if it strays from pure and simple revelation". Thus, Usul al-fiqh bears testimony to the recognition of marvellous exposure beyond that of rationality. The values that must be supported in Islam are not always authenticated only on rationalist grounds. Nevertheless the fact that human reason always played a vital part in the expansion of shari'ah through the medium of ijtihad, the shari'ah itself is primarily founded in divine revelation.

\section{METHODS FOR WAKAF-ZAKAT HOUSING PROVISION RESEARCH}

For wakaf-zakat housing provision research, Table 6 shows the methods employed based on the objectives intended:

Table 6: Objectives-based research methods and their justifications

\begin{tabular}{|c|c|c|}
\hline $\begin{array}{l}\text { Research } \\
\text { objectives }\end{array}$ & $\begin{array}{l}\text { Research } \\
\text { Methods }\end{array}$ & \begin{tabular}{|l|} 
Descriptions/ \\
Justifications
\end{tabular} \\
\hline $\begin{array}{l}\text { 1. to identify } \\
\text { key } \\
\text { indicators in } \\
\text { the } \\
\text { provision of } \\
\text { wakaf-zakat } \\
\text { housing }\end{array}$ & \multirow{2}{*}{$\begin{array}{l}\text {-focus-group } \\
\text { discussion } \\
\text { (FGD) } \\
\text {-observation } \\
\text {-case study } \\
\text {-interview }\end{array}$} & \multirow{2}{*}{$\begin{array}{l}\text { From an extensive literature } \\
\text { review, instrument for data } \\
\text { collection was formulated. } \\
\text { Originally, the FGD is } \\
\text { planned as part of data } \\
\text { collection; however due to } \\
\text { transdisciplinary research } \\
\text { between Islamic studies and } \\
\text { the built environment of } \\
\text { which the experts invited } \\
\text { for FGD are knowledgable } \\
\text { in either Islamic studies or } \\
\text { built environments } \\
\text { separately, the session } \\
\text { becomes piloting only. } \\
\text { Objectives } 1 \text { and } 2 \text { are more } \\
\text { achievable via } \\
\text { identification of } \\
\text { wakaf-zakat housing project } \\
\text { making them as case } \\
\text { studies, and observations by } \\
\text { visiting the sites while } \\
\text { interviewing the person in } \\
\text { charge. }\end{array}$} \\
\hline $\begin{array}{l}\text { 2. to determine } \\
\text { the shariah } \\
\text { legitimacy } \\
\text { based on (1) } \\
\text { in the } \\
\text { provision of } \\
\text { wakaf-zakat } \\
\text { housing }\end{array}$ & & \\
\hline $\begin{array}{l}\text { 3. to develop } \\
\text { an } \\
\text { appropriate }\end{array}$ & $\begin{array}{l}\text {-content } \\
\text { analysis of the } \\
\text { collected data }\end{array}$ & $\begin{array}{l}\text { The procedure of recording } \\
\text { and transcribing were } \\
\text { undertaken as part of the }\end{array}$ \\
\hline
\end{tabular}

\begin{tabular}{|l|l|l|}
\hline $\begin{array}{l}\text { benchmark } \\
\text { for } \\
\text { assessing } \\
\text { the shariah } \\
\text { legitimacy } \\
\text { in the } \\
\text { provision of } \\
\text { wakaf-zakat }\end{array}$ & & content analysis. \\
\hline $\begin{array}{l}\text { 4. to validate } \\
\text { the } \\
\text { benchmark } \\
\text { established } \\
\text { in (3) } \\
\text { above. }\end{array}$ & ussionterview/foc & The analysis was presented \\
\hline
\end{tabular}

\section{A. Focus Group Discussion}

In theory, group discussions are done with the involvement of multiple persons to utilize their skills and opinions about particular matters closely associated with research question(s). For the purpose of wakaf-zakat housing research, fifty-two experts from different professional backgrounds namely wakaf-zakat researchers, architects, religious authority, housing developer, Islamic banking practitioners, property agent and local authority were invited. Thirty-one of them attended the discussion managed by a moderator who is aliable to confirm that group discussions endure fixated on the research topic. The research was briefed to them with the intended objectives to achieve. They were asked to fill up the survey form contained mainly on the shariah matters arising from the wakaf-zakat housing provision. The forms were collected at the end of the session; however the outcome was not very convincing. While experts with religious studies background can respond to it reasonably, those without this background, their responses were considered minimal or not at all. Nevertheless, the FGD helped to pilot the survey and to confirm the issue of wakaf-zakat housing provision that requires attention from both religious authorities and the built environment professionals.

\section{B. Case-Studies}

From the literature reviews, several case studies on wakaf-zakat housing provision were identified. The details of the case-studies were obtained either by reading a project file at the relevant authorities, for example, JAWHAR and YWM or site-visit by way of observations or both ways.

\section{Observation}

For wakaf-zakat housing provision research, site-visits to twenty wakaf/zakat housing projects throughout Peninsular Malaysia were conducted. Among others, the name of the project, the developer involved, the stakeholders, the agreement and procurement system undertaken, the size of the project etc were recorded.

\section{Interview}

Interviews were accompanied by the relevant authorities mainly SIRC, Mufti's Department, developers, banks and wakaf/zakat authorities at the initial stage of data collection. Twenty institutions involved 
with high degree of respondent selected criteria. The interviewees must be an officer who is handling the wakaf-zakat development at their offices be it.SIRC, developer, bank or wakaf-zakat authority, meanwhile Mufti or his Deputy or head of Fatwa Division at Mufti's Department were selected for the interviews.

In summary, Table 7 shows the number of institutions/authorities involved in each research method undertaken by the wakaf-zakat housing provision research.

\begin{tabular}{|c|c|c|c|c|c|c|c|c|c|}
\hline \begin{tabular}{|l|} 
Meth \\
ods
\end{tabular} & $\begin{array}{l}\text { Number } \\
\text { involved }\end{array}$ & of $i$ & nstitu & ions/a & uthoriti & $\mathrm{ies} / \mathrm{st}$ & & & $\begin{array}{l}\text { To } \\
\text { tal } \\
\end{array}$ \\
\hline FGD & \begin{tabular}{|l} 
Researc \\
her/ \\
academ \\
ician \\
$(10)$
\end{tabular} & \begin{tabular}{|l}
$\mathrm{Ba}$ \\
$\mathrm{nk}$ \\
$\mathrm{er}$ \\
$(2)$
\end{tabular} & \begin{tabular}{|l|} 
Arc \\
hite \\
ct \\
$(4)$
\end{tabular} & $\begin{array}{l}\text { Relat } \\
\text { ed } \\
\text { autho } \\
\text { rities } \\
(6)\end{array}$ & \begin{tabular}{|l|} 
Relig \\
ious \\
autho \\
rity \\
$(8)$ \\
\end{tabular} & \begin{tabular}{|l} 
Dev \\
elop \\
er \\
$(1)$
\end{tabular} & & & 31 \\
\hline $\begin{array}{l}\text { Case- } \\
\text { study } \\
/ \\
\text { obser } \\
\text { vatio } \\
\text { ns } \\
\end{array}$ & $\begin{array}{l}\text { Penang } \\
(6)\end{array}$ & $\begin{array}{l}\mathrm{Ke} \\
\mathrm{da} \\
\mathrm{h} \\
(2)\end{array}$ & \begin{tabular}{|l} 
Kela \\
ntan \\
$(3)$
\end{tabular} & $\begin{array}{l}\text { Tere } \\
\text { ngga } \\
\text { nu } \\
(2)\end{array}$ & $\begin{array}{l}\text { Johor } \\
(2)\end{array}$ & $\begin{array}{l}\text { Pah } \\
\text { ang } \\
(2)\end{array}$ & $\begin{array}{l}\text { M } \\
\text { ela } \\
\text { ka } \\
(2)\end{array}$ & $\begin{array}{l}\text { Sel } \\
\text { an } \\
\text { go } \\
\text { r } \\
(1)\end{array}$ & 20 \\
\hline $\begin{array}{l}\text { Interv } \\
\text { iews }\end{array}$ & $\begin{array}{l}\text { SIRC } \\
(7)\end{array}$ & $\begin{array}{l}\mathrm{Mu} \\
\mathrm{fti} \\
\mathrm{De} \\
\mathrm{par} \\
\mathrm{tm} \\
\mathrm{ent} \\
(6)\end{array}$ & $\begin{array}{l}\text { Dev } \\
\text { elop } \\
\text { er } \\
(6)\end{array}$ & $\begin{array}{l}\text { Bank } \\
(1)\end{array}$ & \begin{tabular}{|l} 
Rese \\
arche \\
r/ \\
acade \\
micia \\
n (5)
\end{tabular} & & & & 25 \\
\hline
\end{tabular}

Analysis of Data through Content Analysis

Figure 5 and Table 4 illustrates the qualitative content analysis.

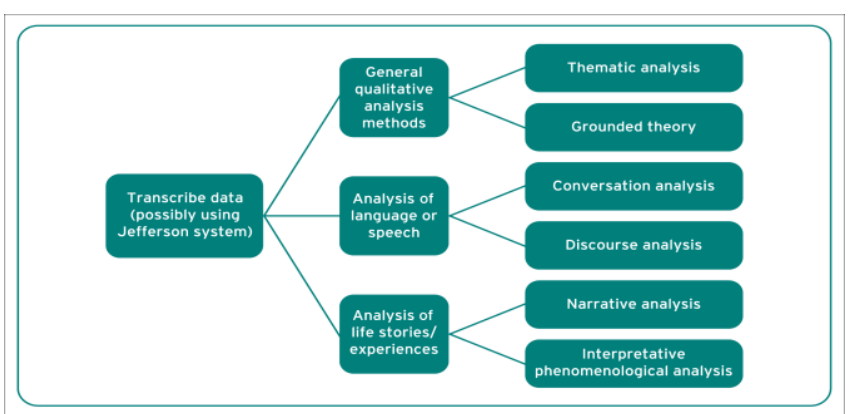

Fig. 5: Transcribing in contemporary qualitative research. Source: Coolican, H. (2004).

Table 4: Description of various methods of qualitative analysis

\begin{tabular}{|c|c|}
\hline Thematic analysis & $\begin{array}{l}\text { The epistemological basis of thematic analysis is relatively unspecific other than } \\
\text { it follows the broad general features of qualitative approaches. }\end{array}$ \\
\hline Grounded theory & $\begin{array}{l}\text { Grounded theory is a reaction to the large-scale social theory of sociology prior } \\
\text { to the } 1960 \text { s. It provided rigorous methodological procedures for theory building. }\end{array}$ \\
\hline Discourse analysis & $\begin{array}{l}\text { The roots of discourse analysis are in the idea of speech as action as well as } \\
\text { Foucault's approach to social systems. }\end{array}$ \\
\hline Conversation analysis & $\begin{array}{l}\text { Conversation analysis adopts a strongly ethnomethodological approach to lan- } \\
\text { guage in its attempt to understand conversation as a skilled performance. }\end{array}$ \\
\hline $\begin{array}{l}\text { Interpretative } \\
\text { phenomenological analysis }\end{array}$ & $\begin{array}{l}\text { Interpretative phenomenological analysis is strongly based on phenomenology } \\
\text { and a number of related approaches. It concentrates on experiences as experi- } \\
\text { enced by the individual. }\end{array}$ \\
\hline Narrative psychology & $\begin{array}{l}\text { Narrative psychology concentrates on life-story data which it interprets from a } \\
\text { critical realist perspective. In many respects it shares many of the perspectives } \\
\text { of interpretative phenomenological analysis. }\end{array}$ \\
\hline Phenomenology & $\begin{array}{l}\text { Phenomenology is the philosophical system of Edmund Husserl which has found } \\
\text { expression in psychology as phenomenological psychology. This involves a } \\
\text { variety of methods which adhere, to differing extents, to Husserl's philosophy. It } \\
\text { concentrates on how things are experienced in consciousness. }\end{array}$ \\
\hline
\end{tabular}

Source: Coolican, H. (2004).

The analysis resulted in a benchmark for shariah-compliant wakaf-zakat housing provision. The second round of interviews was conducted with the selected Mufti(s) for the validation of the benchmark developed. More specifically, the benchmark developed based on indicators and shariah legitimacy identified in Objectives 1 and 2 respectively was submitted to the Fatwa Division of the selected Mufti's Department for deliberation. The religious view issued was undertaken as a guideline for the implementation of wakaf-zakat housing projects.

\section{CONCLUSION}

Wakaf-zakat housing provision research is qualitative based on the objectives. Therefore, qualitative research methods for each objective follow suit notably FGD, case-study, observation and interview. The data collected via various qualitative methods were analysed using content analysis. As a result a benchmark for wakaf-zakat housing provision shariah legitimacy was established, and a proposal paper was prepared for the deliberation by the Fatwa division at the Mufti's department.

In general, there is relatively no much difference between ijtihad and contemporary research practice in terms of their rigorousness. Both are governed by certain steps and procedures. More importantly, they acknowledge probabilistic nature of research. In other words, the idea of truth is separate from the creative realm of thinking by scholars. Another set of findings is while both Islam and secular promote research and it was regulated by certain methods, Islamic research is based on Quran and Sunnah as a principal source of knowledge. its input or source of knowledge is primarily founded in divine revelation, i.e. Al-Quran and Al-Sunnah. Rationality alone is not an independent proof in Islam. This is among the reasons why Islamic jurisprudence exhibits greater stability and continuity of values, thought and institutions compared to other jurisprudences.

\section{ACKNOWLEDGEMENTS:}

This research was completed with the financially support of Transdisciplinary Research Grant Scheme (TRGS) 2016 (Project ID: TRGS16-01-005-0005) Ministry of Education, Malaysia.

\section{REFERENCES}

[1] Eza Ellany Abdul Lateff, Mohd Rizal Palil, Mohamat Sabri Hassan 2014. Financial and non-financial Distribution Efficiency Performance Among Zakat Institutions in Malaysia. Jurnal Ekonomi Malaysia 48(2), pp.51-60.

[2] Government of Malaysia. 2016. Providing adequate and quality affordable house.

[3] Ministry of Housing and Local Government. 2017. National Physical Plan. Government of Malaysia.

[4] Sharifah Zubaidah Syed Abdul Kader \& Nor Asiah Mohamed. 2017. The Legal Position of Waqf Land in Malaysia. In Syed Khalid Rashid (Ed.). Waqf Laws and Management. IIUM Press.

[5] UDA Holdings Sdn Bhd. 2017. Development of waqaf land: Case study of waqaf Seetee Aisah, Pulau Pinang. Unpublished. 
[6] Yayasan Waqaf Malaysia. 2016. Waqaf Property Development Transformation. Gov. of Malaysia.

[7] Yusuf al-Qardawi (translated by Monzer Kahf). (n.d). Fiqh al-Zakah. Scientific Publishing Centre, King Abdul Aziz University, Jeddah, Saudi Arabia.

[8] Shawki Ismail Shehata. (1985). Limitations on the Use of Zakah Funds in Financing Socio-economic Infrastructure.

[9] Patmawati Ibrahim and Ruziah Ghazali. (2014). Zakah as An Islamic Micro-Financing Mechanism to Productive Zakah Recipients. Asian Economic and Financial Review, 4(1): 117-125.

[10] Azila Ahmad Sarkawi, Khairuddin Abdul Rashid, Sharina Hassan. (2015). Penyediaan Tempat Tinggal Golongan Asnaf Menurut Skim Bantuan Agihan Zakat: Cadangan Penggunaan Tanah Wakaf. Jurnal Pengurusan Jawhar. 9(1).

[11] Azman Ab Rahman \& Hasanah Abd. Khafidz. (2015). Ensiklopedia Asnaf dan Skim Agihan Zakat di Malaysia. USIM Press.

[12] 'AbdulHamid A. AbuSulayman. 1994. Islamization: Reforming Contemporary Knowledge. International Institute of Islamic Thought.

[13] Coolican, H. (2004). Research Methods and Statistics in Psychology (Fourth Edition). London, UK; Hodder \& Stoughton.

[14] Muhammad Hashim Kamali.1991. Principle of Islamic Jurisprudence, Second Revised Edition, Ilmiah Publishers

[15] Jasser Auda. 2008. Maqasid al-Shari'ah as Philosophy of Islamic Law. IIIT, USA.

[16] Eyad. 2012. Usool Fiqh Science and General Research Methods Approach and Comparison. Journal paper produced by Kuwait University.

[17] http://www.businessdictionary.com/definition/research.html

[18] Mohammad Muaz Jalil, www.Enterprise-Development.org

\section{AUTHOR'S PROFILE}

Azila Ahmad Sarkawi, is affiliated with International Islamic University Malaysia. The area of Expertise includes Policy research.

Jamilah Othman, International Islamic University Malaysia. The area of expertise is landscape Ecology, Nature based Tourism, Landscape Mnagement of natural resources-scenic beauty. 